\title{
Supplementation of pigs diet with zinc and copper as alternative to conventional antimicrobials
}

\author{
B. Dębski \\ Warsaw University of Life Sciences, Faculty of Veterinary Medicine \\ Nowoursynowska 159, 02-787 Warsaw, Poland
}

\begin{abstract}
Modern commercial pig farming systems inflict increased stress in animals, which often leads to various negative changes in the gastro-intestinal tract, especially in the case of piglets. Ban of antibiotics, used as growth promoters, has caused a need for alternatives to conventional antimicrobials in swine diets. Use of pre-/or probiotics, organic acids and plant extracts is often recommended, but it seems that zinc oxide and cooper salts, which were traditionally included in high doses to piglets diet, possess the highest efficacy. In commercial conditions feeding piglets with high doses of $\mathrm{Zn}$ and/or $\mathrm{Cu}$ stimulates piglets daily gain and decreases feed conversion factor. However, as heavy metals $\mathrm{Zn}$ and $\mathrm{Cu}$ tend to accumulate in soil and cause serious environmental pollution of soil and tap-water. Furthermore, high zinc concentrations $(2500 \div 3000 \mathrm{mg} / \mathrm{kg}$ feed) in feed may have an impact on development of antimicrobial resistance, and may regulate the expression of genes that modify piglets' immune response. Therefore, the use of high doses of $\mathrm{ZnO}$ and/or $\mathrm{Cu}$ salts, as growth promoter, has always been a subject of discussion, and caused different legal status of such treatment in various EU countries. This short review describes current European Food Safety Authority (EFSA) point of view on the use of $\mathrm{ZnO}$ in medicated feed. The higher bioavailability of recently introduced new sources or forms of these metals allows for substantial reduction of dietary inclusion rate, which should have a positive outcome for pigs health and the environment.
\end{abstract}

Key words: $\mathrm{ZnO}$, pig, dietary supplement, alternative antimicrobials, growth promoters

Conditions of modern commercial pig farming inflict different type of stress which is associated with significant negative impact (physiological, microbiological and immunological) on the gastro-intestinal tract in housed animals. These stress-related changes lead to sub-optimal growth, decrease feed efficiency and increase incidences of intestinal disturbances, including diarrhoea. Post-weaning diarrhea is one of the most frequent causes of economic losses dealing with pigs. To minimize all these negative changes antibiotics were extensively used in pig farming, which, in turn, caused a development of increased antibiotic resistance in numerous bacterial strains. As a consequence, in 2003 the use of in-feed antibiotics in livestock diets was banned in the EU (Regulation No. 1831/2003). 
Some minerals and/or pre- and probiotics, acidifiers, and plant extracts may serve as alternative to antibiotics used as growth promoters in weaning piglets (Vondruskova et al. 2010, Thacker 2013).

Zinc oxide $(\mathrm{ZnO})$ has been traditionally included in diets for weaning pigs since early 1990's. However, use of $\mathrm{ZnO}$, as growth promoter, has always been a subject of discussion because although it promotes piglets' health and performance, it is a compound containing heavy metal $(\mathrm{Zn})$, which may be toxic in concentrations used. Feeding high concentrations of $\mathrm{ZnO}$ has been demonstrated to reduce diarrhoea incidences and improve piglets' growth. Based on data published by Moreno (2012) in Spain 57\% of piglets were given $\mathrm{ZnO}$ during pre-weaning stage of life and $73 \%$ during the growing stage (27-75 days).

Numerous studies have demonstrated growth-promoting effect of $\mathrm{ZnO}$ (Mavromichalis et al. 2000, Grela and Pastuszak 2004, Li et al. 2006a, Cho et al. 2015). Use of different $\mathrm{Zn}$ sources, including $\mathrm{ZnO}$ and $\mathrm{Zn}$-chelates, in commercial pig farming, shows positive response in growth and feed conversion rate. Mullan et al. (2007) demonstrated significant differences in average daily gain (ADG) (day 0-39) of piglets which did not receive any $\mathrm{Zn}$ supplementation $(367 \mathrm{~g})$ in comparison to those fed diets containing $\mathrm{Zn}$ (389-427g, depending on the type of supplementation). Furthermore, the authors observed a reduction in feed conversion ratio (FRC) from 1.58 (control) to 1.36-1.38 (experimental groups). Another study showed that microbial fecal score was improved during 21 day of life in piglets treated with organic $\mathrm{Zn}$ (Castillo et al. 2008).

$\mathrm{Zn}$ is used to decrease fermentation of digestible nutrients in intestines, improve nutrients digestibility and to improve appetite. Dietary $\mathrm{Zn}$ supplementation stimulates feed intake probably caused by increased ghrelin secretion (Yin et al. 2009). It was observed that it caused an increase in insulin-like growth factor expression in the small intestine mucosa ( $\mathrm{Li}$ et al. 2006a). Increased $\mathrm{Zn}$ concentration in the intestines influences their structure and function. Increased height of small intestine villi in comparison with the depths of crypts was observed by Castillo et al. (2008) in $\mathrm{ZnO}$ treated pigs. Pharmacological doses of $\mathrm{Zn}$ affect not only colonic morphology but also host defense mechanisms. However, in piglets used in experiments by Liu et al. (2014) the highest colonic crypt area was found in piglets treated with much lower dose of $\mathrm{ZnO}(164 \mathrm{mg} / \mathrm{kg}$ feed). Also higher colonic crypt area and mRNA expression of cytokines and composition of intestinal mucins in such piglets was found (Liu et al. 2014). All these observations suggest that the local level of $\mathrm{Zn}$ plays a significant role in the mechanism of $\mathrm{ZnO}$ action, especially since it was shown that $\mathrm{Zn}$ bioavailability is not a significant factor influencing its efficacy (Mavromichalis et al. 2000). The $2000 \mathrm{mg} / \mathrm{kg}$ feed dose of $\mathrm{ZnO}$ caused 3 to 5 fold increase in $\mathrm{Zn}$ concentration along the gastrointestinal tract, and a slight increase of copper concentration in the blood, compared to those determined in unsupplemented piglets (Davin et al. 2012).

Dose-dependent effects of $\mathrm{ZnO}$ on composition of bacterial communities and metabolic properties were observed in the ileum of weaned piglets (Pieper et al. 2012). The number of food borne pathogens such as Salmonella typhimurium and Staphylococus aureus was significantly reduced, suggesting that $\mathrm{ZnO}$ might be used as antimicrobial agent and even to reduce antibiotic-resistant strains of bacteria present in the digestive tract (Thati et al. 2010). The results of specific viral pathogens challenge of pigs indicated that the use of high concentrations of dietary zinc could enhance protection of the treated animals (Chai 2013). However, it was also found that prolonged (over 4 weeks) use of such high $\mathrm{Zn}$ supplemented diets caused growth reduction and could increase some forms of resistance in intestinal microbes. It was also observed that very high level of maternal dietary zinc $(5 \mathrm{~g} / \mathrm{kg}$ feed) reduces copper body stores in newborn piglets (Hill et al. 1983).

$\mathrm{Zn}$ mechanism of action against diarrhea is still not well understood. Zhang and Guo (2009) have speculated that high concentrations of dietary Zn decreases intestinal permeability preventing translocation of pathogenic bacteria through the intestinal barrier. It was also shown that weaning creates $\mathrm{Zn}$ deficiency in piglets (Davin et al. 2013). However, in diarrhea treatment only high pharmacological doses of $\mathrm{ZnO}$ are efficient (2000-3000 mg/kg feed). Such concentrations are very high because maximum tolerable concentration for pigs was estimated to be $1000 \mathrm{mg} / \mathrm{kg}$ feed (NRC 2005). Treatment with Zn using such high doses of $\mathrm{ZnO}$ is beneficial to piglets only during early phases of nursery period. The feeding period of high $\mathrm{ZnO}$ doses should be limited to 2-3 weeks after weaning.

The use of $\mathrm{ZnO}$ at high concentrations $(\geq 2500$ $\mathrm{mg} / \mathrm{kg}$ feed) in medicated feed is allowed in EU countries except Germany, France and The Netherlands. In Poland, Portugal, Spain, Sweden and UK ZnO is allowed in treatment of piglets diarrhea, administered at the concentration of $3000 \mathrm{mg} / \mathrm{kg}$ feed for 2-6 weeks. In Poland medicated premix Suibicol is registered, which contains $\mathrm{ZnO}$ in final feed concentration of $3000 \mathrm{mg} / \mathrm{kg}$ feed and sulphaguanidin in final feed concentration $2000 \mathrm{mg} / \mathrm{kg}$ feed. This premix is recommended for use in weaned piglets for 10 to 14 days. Medicated feed containing this product requires veterinary prescription. $\mathrm{ZnO}$ has been allowed as feed 
additive in Europe, and EFSA considered this additive as safe for target animals and consumers in feed at maximum concentration of $150-200 \mathrm{mg} / \mathrm{kg}$ feed. The newly proposed maximum total $\mathrm{Zn}$ concentration in complete feed for piglets and sows is $150 \mathrm{mg} / \mathrm{kg}$ feed (EFSA 2014).

Also copper was shown to stimulate growth rate of piglets when included into diet at high levels (125-250 $\mathrm{mg} / \mathrm{kg}$ feed). Armstrong et al. (2004) observed that the concentration of copper at the level of $125 \mathrm{mg} / \mathrm{kg}$ feed have similar effect on growth of weanling piglets, regardless the copper source. The inclusion of $\mathrm{Cu}$ to starter diets for weaning pigs is a common practice in swine industry. $\mathrm{Cu}$ is mostly used as copper sulfate but Cromwell et al. (1998) showed similar efficacy in the case of tri-basic copper chloride. The growth-stimulating properties of dietary copper have been attributed to its antimicrobial action however, it was shown that also intravenous injection of copper to weanling piglets stimulate their growth (Zhou et al. 2014). It seems that the growth-promoting properties of high dietary concentrations of copper are in addition to its antimicrobial action (Jacela et al. 2010). Hojberg et al. (2005) found that administration of $175 \mathrm{mg} / \mathrm{kg}$ feed $\mathrm{CuSO}_{4}$ reduced amounts of lactic acid bacteria, lactobacilli and streptococci in the gastrointestinal tract of pigs. It is interesting that in cooper treated piglets a reduced number of lactic acid bacteria was observed because this group of commensal bacteria are considered very important for stabilization of the gut ecosystem. However, decreased level of these commensals in the proximal part of the gastrointestinal tract may benefit by allocation of increased feed amount for growth performance. Carlson et al. (2004) suggest that observed reduction of coliforms in the large intestine of $\mathrm{Cu}$-supplemented piglets may be a part of mechanism influencing the suppression of growth and causing reduced number of the specific pathogens in the digestive tract.

Nutritional requirement of $\mathrm{Cu}$ is about $5 \mathrm{mg} / \mathrm{kg}$ feed, but the mechanism of action of high pharmacological $\mathrm{Cu}$ doses $(125-250 \mathrm{mg} / \mathrm{kg}$ feed), is not recognized. In the majority of experiments, piglet diets were supplemented with $250 \mathrm{mg} / \mathrm{kg}$ feed. However, the European Commission (2003) extrapolated Cu concentration, acting as growth promoter, at the level of 175 $\mathrm{mg} / \mathrm{kg}$ feed, based on $\mathrm{Cu}$ inclusion levels currently allowed in EU countries. It seems that copper given in such a dose modifies the composition of bacterial population in the gastro-intestinal tract. There are significant differences in the bioavailability of $\mathrm{Zn}$ and $\mathrm{Cu}$ originating from different sources; that is why only the recommended sources of these minerals can be used in pigs for growth promotion. A response of piglets to high doses of $\mathrm{Cu}$ and $\mathrm{Zn}$ seems to be independent of other antimicrobials in the diet (Cromwell et al. 1997). Copper and zinc are efficacious even in the presence of antibiotics, suggesting their different modes of action. It was observed that high dietary level of copper may cause increased content of unsaturated fatty acids, which resulted in softer pork fat, but this effect could be minimized by reduction in $\mathrm{Cu}$ dosage before slaughter.

\section{High dose $\mathrm{ZnO}$ - side effects}

\section{Environmental issue}

As a heavy metal $\mathrm{Zn}$ tends to accumulate in soil and may cause serious environmental pollution, especially in areas with intensive pig farming. Environmental concern is related to groundwater, drainage and $\mathrm{Zn}$ run-off to the surface water. Sandy soils are most vulnerable to these processes. Another point is accumulation of $\mathrm{Zn}$ in topsoil to concentrations potentially toxic to organisms living there. The use of high doses of $\mathrm{ZnO}$ in pig farming causes increased $\mathrm{Zn}$ excretion which might be a real threat to the environment (Heo et al. 2013). Increased excretion of heavy metals $(\mathrm{Zn}, \mathrm{Cu})$ could be a potential problem in off-site nurseries where weanling piglets are farmed year around. Use of high doses of $\mathrm{Zn}$ and $\mathrm{Cu}$ cause visible changes of sows feces e.g. increased fecal firmness was observed. Addition of $\mathrm{ZnO}$ causes disappearance of characteristic black color of feces in copper supplemented piglets. Zinc and copper are not degradable in the slurry and their increased consumption in modern pigs farming cause accumulation of $\mathrm{Zn}$ and $\mathrm{Cu}$ in the slurry. Roof and Mahan (1982) reported that piglets supplementation with $\mathrm{CuSO}_{4}$ at the level of $250 \mathrm{mg} \mathrm{Cu} / \mathrm{kg}$ feed caused 14 times increase of fecal copper excretion. National monitoring study performed in Denmark has revealed that current use of zinc and copper for pig production may pose environmental pollution and a serious risk to aquatic animals (Jensen et al. 2016). However, $\mathrm{ZnO}$ provided feasible alternative to in-feed antibiotics and its reduction of inclusion level might be obtained by introduction of new, more efficient $\mathrm{Zn}$ compounds and/or forms. Increased heavy metals emission has adverse environmental effects, like impairment of plant production, accumulation of these metals in water supply chain and induction of antimicrobial resistance (Brugger and Windisch 2015).

\section{Antimicrobial resistance}

Development of antibiotic-resistant bacterial strains and their potential impact on human health elicits an increasing concern. Studies have shown 
that $\mathrm{Zn}$ and $\mathrm{Cu}$ used at high concentrations for a longer period might promote the spread of antimicrobial resistance of gut microflora in pigs (Holzel et al. 2012). It was demonstrated that prolonged exposure to pharmacological doses of $\mathrm{Zn}$ can increase the resistance in some form of microbes e.g. increased number of multi-resistant Escherichia coli in piglets treated for 4 weeks with $2500 \mathrm{mg} / \mathrm{kg}$ feed of $\mathrm{ZnO}$ (Bednorz et al. 2013). Slifierz et al. (2014) observed increased prevalence and persistence of methicillin-resistant Staphylococcus aureus in post weaning piglets treated with high doses of dietary $\mathrm{ZnO}$. The results of a study by Agga et al. (2015) obtained on weaned pigs fed 3 weeks copper sulfate $(125 \mathrm{mg}$ $\mathrm{Cu} / \mathrm{kg}$ feed) suggest that $\mathrm{Cu}$ supplementation may have significant impact on certain gens expression. The prolonged use of heavy metals such as $\mathrm{Zn}$ and $\mathrm{Cu}$ provides selective pressure on antimicrobial-resistant bacteria and this is a reason why implementation of high doses of these metals may play a role in maintaining of antimicrobial resistance (Holman and Chenier 2015).

\section{Nutritional interactions of zinc/copper with products reducing use of antibiotics}

\section{Zinc/copper interaction}

Administration of $\mathrm{Zn}$ and $\mathrm{Cu}$ together usually does not cause additive effects, however, Perez et al. (2011) observed appearance of additive effect of supplementation with pharmacological amounts of $\mathrm{ZnO}$ and $\mathrm{CuSO}_{4}$ on weaning piglets growth. Shelton et al. (2011) have shown advantages of inclusion of $\mathrm{Zn}$ and $\mathrm{Cu}$ in the pigs diet when $\mathrm{Zn}$ was added from 0 to 14 days postweaning and $\mathrm{Cu}$ from 14 to 42 days postweaning. Jongbloed et al. (2011) quantified the dose-response relationship of supplemented $\mathrm{Cu}$ on growth performance and they found the highly significant relation in piglets weighted from 5 to $25 \mathrm{~kg} \mathrm{BW}$.

Another strategy to minimize a transient drop in feed intake, growth and increased sensitivity to digestive diseases (diarrhea) is the use of various nutritional approaches. Enrichment of the feed with substances that show various properties, such as: anti-microbial and/or immune stimulating properties or appetite stimulation may exert a positive effect on the health status of farmed piglets.

\section{Probiotics}

Probiotics are living cultures of microorganisms which administered in adequate amounts exerting beneficial effect on host, improving the indigenous microbial balance. Function of probiotics in the digestive tract is suggested to consist in: competing with pathogenic bacteria for nutrients and binding sites on the intestinal wall, stimulation of the immune system and production of compounds that are toxic for pathogens (Cho et al. 2011). Enterococcus faecium NCIMB 10415 is authorized in the EU as a probiotic feed additive for pigs and Wang et al. (2014) have shown that the use of this probiotic bacteria have the same beneficial effect on weight gains as supplementation of piglets with $\mathrm{ZnO}$ at the level of $2500 \mathrm{mg} / \mathrm{kg}$ feed.

\section{Prebiotics}

Prebiotics defined as non-digestable feed components that positively affect animal health by selective stimulation of beneficial intestine bacteria. Example of such substances are yeast derivate - different kinds of polysaccharides are able to modulate immune functions in piglets. It has been shown that $\beta$-glucans possess anti-inflammatory properties enhancing anti-inflammatory cytokine production in pigs $(\mathrm{Li}$ et al. 2006). In some situations, glucans may stimulate growth and feed intake but also depress piglet's performance (Hahn et al. 2006).

\section{Plant extracts}

Seaweed extract containing complex polysaccharides added to piglets feed was found to possess growth promoting properties similar to those of $\mathrm{ZnO}(\mathrm{McAl}-$ pine et al. 2012). Lipinski et al. (2014) observed that use blend of organic acids, plant extracts with mineral clays (B-Safe supplement) or $\mathrm{ZnO}$ in weaning pigs improved the digestibility of crude protein and nitrogen retention. The lowest feed conversion ratio was found in piglets fed zinc oxide and in the pigs fed with nutritional supplement B-Safe containing plant extracts. Several studies have reported that essential oils of labiates plants (oregano, thyme, rosemary) stimulate growth performance of piglets but other scientists have not observed such influence. Most studies showing bactericidal or bacteriostatic effect on several pathogenic intestinal microorganisms were performed only in vitro. It is possible that labiatae oils mode of action is connected with their high anti-oxidative potential.

\section{Acidifiers}

Another group of substances used in pig farming with proven efficiency providing positive influence on 
digestive microbiota are organic acids commonly used in animal nutrition. Acidic growth promoters act by lowering the $\mathrm{pH}$ of the digestive tract content and/or by effective antibacterial function. However, zinc oxide acid binding capacity is very high (similar to limestone flour) and in case of high $\mathrm{ZnO}$ diet enrichment it appears to be antagonistic with such feed acidifiers like organic acids. Lactic, fumaric and citric acids reduce bacterial population indirectly by lowering stomach $\mathrm{pH}$. Another group of acids consist of formic, acetic, propionic and sorbic acid. These acids are directly acting on gram-negative bacteria by lowering the $\mathrm{pH}$, thus preventing their replication (Castro 2005). A combination of different organic acids leads to suppression of E. coli, Salmonella and Enterococcus $s p$. in pigs' digestive tract causing growth improvement (Missotten et al. 2009). However, as alternative to antibiotics, organic acids not fully ameliore negative effects of microbial challenges e.g. using Salmonella enterica or Escherichia coli KCTC 2571 on growth performance and immunity of pigs (Ahmed et al. 2014). Lampromsuk et al. (2012) based on results of experiment with the use of $\mathrm{ZnO}(2300 \mathrm{mg} \mathrm{Zn} / \mathrm{kg}$ feed), $\mathrm{Zn}$ acetate ( $\mathrm{Zn} 500 \mathrm{mg} / \mathrm{kg}$ feed) or acidifier based on sodium benzoate $(3000 \mathrm{mg} / \mathrm{kg}$ feed) have concluded that piglets supplementation of organic zinc between 24 and 45 day of life with addition of acidifiers at 24-73 day of life may increase their growth performance.

\section{Future perspectives of using minerals as alternatives to conventional antimicrobials}

Different mixtures of phytogenic substances may have additive effects increasing antioxidant status and/or improving immune status, or beneficially modulating gut microbiota composition. These positive changes should improve growth performance and health status of piglets. Zinc oxide supplied at pharmacological level evidently improves weaned pig performance and is cheap what may led to inappropriate usages, environmental $\mathrm{Zn}$ accumulation and increase of bacterial resistance.

Hernandez et al. (2008) have demonstrated that the use of dietary $\mathrm{Cu}$ and $\mathrm{Zn}$ organic complexes, which show higher bioavailability, enabled to obtain increased improvement of the performance of pigs in comparison to that observed in the animals receiving supplementation with inorganic sources of these metals. For example, $\mathrm{Zn}$ in TM bioplexes may be used in concentrations of 100 and $250 \mathrm{mg} / \mathrm{kg}$ feed still showing some positive impact on piglets growth (Mullan et al. 2007).
Another way to reduce the amount of $\mathrm{ZnO}$ added to the feed is increasing the active surface area of $\mathrm{ZnO}$ by the use of high porosity product or introduction of nanopreparats. Initial trials with this form of $\mathrm{ZnO}$ have been shown to be very promising. Nano-grinding of $\mathrm{ZnO}$ has several times larger surface of interaction with the gastrointestinal tissue and microbial population. The introduction of new generation of $\mathrm{Zn}$ compounds e.g. zinc-doped copper oxide nanoparticles (Malka et al. 2013) seems also very promising. Tayel et al. (2011) observed very strong antibacterial properties of $\mathrm{ZnO}$ powder given in a form of nanoparticles. Genotoxicity of these particles is rather low. However, in vitro studies on cell lines have shown that induction of genotoxic cell damage and increased frequency of micronuclei is also observed at $\mathrm{ZnO}$ concentrations below $100 \mu \mathrm{g} / \mathrm{ml}$ (Demir et al. 2014). Antibacterial properties and toxicity mechanism of zinc oxide nanoparticles were described by Sirelkhatim et al. (2015). In methicillin-resistant $S$. epidermidis strains $\mathrm{ZnO}$ nanoparticles caused decreased bacterial growth (Ansari et al. 2012). There is however, a concern dealing with the use of high doses of $\mathrm{ZnO}$ due to its potential impact on the expression of genes encoding proteins associated with inflammatory response in piglets (Sargeant et al. 2010). This property of $\mathrm{ZnO}$ indicates possible modifications of host's immune response to compounds responsible for initiation of inflammatory processes.

Recently microencapsulated $\mathrm{ZnO}$ was released on the market with intended dose of $\mathrm{Zn}$ decreased to only $100 \mathrm{mg} / \mathrm{kg}$ feed. Results obtained by Kim et al. (2010) have shown beneficial effects of this lipid-coated $\mathrm{ZnO}$, which efficiently suppressed the incidence of post-weaning diarrhea caused by enterotoxigenic E. coli. New forms of $\mathrm{Zn}$ supplementation could provide an effective replacement of traditional $\mathrm{ZnO}$ (added at high concentrations) by reduction of dietary inclusion, but with maintained beneficial effects of $\mathrm{ZnO}$. New potentiated form of $\mathrm{ZnO}$, known as HiZox, was used by Morales et al. (2014) and in inclusion level of $110 \mathrm{mg} \mathrm{Zn} / \mathrm{kg}$ feed it caused growth performance of piglets similar to that observed during regular application of $\mathrm{ZnO}$ given at the dose of $3000 \mathrm{mg} / \mathrm{kg}$ feed.

Furthermore, in the case of organic sources it was possible to lower the level of supplementation with these elements. Very often promising new products are not properly described and the only information concerns e.g. particle size or fact that they are chelated. Nevertheless, it is worth noting that data presented in the literature are very often conflicting and need reevaluation. The majority of the mentioned studies were performed by pharmaceutical companies or were funded by producers of specific supplements. 


\section{References}

Agga GE, Scott HM, Vinasco J, Nagaraja TG, Amachawadi RG, Bai J, Norby B, Renter DG, Dritz SS, Nelssen JL, Tokach MD (2015) Effects of chlortetracycline and copper supplementation on the prevalence, distribution, and quantity of antimicrobial resistance gens in the fecal metagenome of weaned pigs. Prev Vet Med 119: 179-189.

Ahmed ST, Hwang JA, Hoon J, Mun HS, Yang CJ (2014) Comparison of single and blend acidifiers as alternative to antibiotics on growth performance, fecal microflora, and humoral immunity in weaned piglets. Asian-Australas J Anim Sci 27: 93-100.

Ansari MA, Khan HM, Khan AA, Sultan A, Azam A (2012) Characterization of clinical strains of MSSA, MRSA and MRSE isolated from skin and soft tissue infections and the antibacterial activity of $\mathrm{ZnO}$ nanoparticles. World J Microbiol Biotechnol 28: 1605-1613.

Armstrong TA, Cook DR, Ward MM, Williams CM, Spears JW (2004) Effect of dietary copper source (cupric citrate and cupric sulfate) and concentration on growth performance and fetal copper excretion in weanling pigs. J Anim Sci 82: 1234-1240.

Bednorz C, Oelgeschlager K, Kinnemann B, Hartmann S, Neumann K, Pieper R, Bethe A, Semmler T, Tedin K, Schierack P, Wieler LH, Guenther S (2013) The broader context of antibiotic resistance: zinc feed supplementation of piglets increases the proportion of multi-resistant Escherichia coli in vivo. Int J Med Microbiol 303: 396-403.

Brugger D, Windisch WM (2015) Environmental responsibilities of livestock feeding using trace mineral supplements. Anim Nutr 1: 113-118.

Castillo M, Martin-Orue SM, Taylor-Pickard JA, Perez JF, Gasa J (2008) Use of mannanoligosaccharides and zinc chelate as growth promoters and diarrhea preventive in weaning pigs: Effects on microbiota and gut function. J Anim Sci 86: 94-101.

Carlson D, Poulsen DH, Sehested J (2004) Influence of weaning and effect of post weaning dietary zinc and copper on electrophysiological response to glucose, theophylline and 5-HT in piglet small intestinal mucosa. Comp Biochem Physiol A 137: 757-765.

Castro M (2005) Use of additives on the feeding of monogastric animals. Cuban J Anim Sci 39: 439.

Chai W (2013) Effects of zinc supplementation on virus infection in pigs. Freien Universitat Berlin, Journal 3692. www.diss.fu-berlin.de/diss/servlets

Cho JH, Zhao PY, Kim IH (2011) Probiotics as a dietary additive for pigs: a review. J Anim Vet Advances 10: $2127-2134$.

Cho JH, Upadhaya SD, Kim IH (2015) Effects of dietary supplementation of modified zinc oxide on growth performance, nutrient digestibility, blood profiles, fecal microbials shedding and fecal score in weanling pigs. Anim Sci J 86: 617-623.

Cromwell GL (1997) Copper as a nutrient for animals. In: Richardson HW (ed) Handbook of Copper Compounds and Applications. Marcel Dekker Inc., New York, pp 177-202.

Cromwell GL, Lindenmann MD, Monegue HJ, Hall DD, Orr DE (1998) Tribasic copper chloride and copper sulfate as copper sources for weanling pigs. J Anim Sci 76: $118-123$
Davin R, Manzanilla EG, Klasing KC, Perez JF (2012) Evolution of zinc, iron, and copper concentrations along the gastrointestinal tract of piglets weaned with or without in-feed high doses of zinc oxide compared to unweaned littermates. J Anim Sci 90: (Suppl 4): 248-250.

Davin R, Manzanilla EG, Klasing KC, Perez JF (2013) Effect of weaning and in-feed high doses of zinc oxide on zinc levels in different body compartments of piglets. J Anim Physiol Anim Nutr 97, (Suppl. s1): 6-12.

Demir E, Akca H, Kaya B, Burgucu D, Tokgun O, Turna F, Aksakal S, Vales G, Creus A, Marcos R (2014) Zinc oxide nanoparticles: genotoxicity, interaction with UV-light and cell-transforming potential. J Hazard Mater 264: 420-429.

EFSA (2014) Scientific opinion on the potential reduction of currently authorized maximum zinc content in complete feed. EFSA J 12: 3668. www.efsa.europa.eu/efsajournal

European Commission (2003) Opinion of the Scientific Committee for Animal Nutrition on the use of copper in feedingstuffs. 19 Feb. 2003. http://ec.europa.eu/ fs/sc/scan/out115_en

Grela ER, Pastuszak J (2004) Nutritional and prophylactic importance of zinc in pigs production. Med Weter 60: $1254-1258$.

Hahn TW, Lohakare JD, Lee SL, Moon WK, Chae BJ (2006) Effects of supplementation of beta-glucans on growth performance, nutrient digestibility, and immunity in weaning pigs. J Anim Sci 84: 1422-1428.

Hernandez A, Pluske JR, D'Souza DN, Mullan BP (2008) Levels of copper and zinc in diets for growing and finishing pigs can be reduced without detrimental effects on production and mineral status. Animal 2: 1763-1771.

Heo JM, Opapeju FO, Pluske JR, Kim JC, Hampson DJ, Nyachoti CM (2013) Gastrointestinal health and function in weaning pigs: a review of feeding strategies to control post-weaning diarrhoea without using in-feed antimicrobial compounds. J Anim Physiol Anim Nutr (Berl) 97: 207-237.

Hill GM, Ku PK, Miller ER, Ullrey DE, Losty TA, O’Dell BL (1983) A copper deficiency in neonatal pigs induced by a high zinc maternal diet. J Nutr 113: 867-872.

Hojberg O, Canibe N, Poulsen HD, Hedemann MS, Jensen BB (2005) Influence of dietary zinc oxide and copper sulfate on the gastrointestinal ecosystem in newly weaned piglets. Appl Environ Microbiol 71: 2267-2277.

Holman DB, Chenier MR (2015) Antimicrobial use in swine production and its effect on the swine gut microbiota and antimicrobial resistance. Can J Microbiol 61: 785-798.

Holzel CS, Muller C, Harms KS, Mikolajewski S, Schwaiger $\mathrm{K}$, Bauer J (2012) Heavy metals in liquid pig manure in light of bacterial antimicrobial resistance. Environ Res 113: 21-27.

Jacela JY, DeRouchey JM, Tokach MD, Goodband RD, Nelssen JL, Renter DG, Dritz SS (2010) Feed additives for swine: Fact sheets-high dietary levels of copper and zinc for young pigs, and phytase. J Swine Health Prod 18: $87-92$

Jensen J, Larsen MM, Bak J (2016) National monitoring study in Denmark finds increased and critical levels of copper and zinc in arable soils fertilized with pig slurry. Environ Pollut 214: 334-340.

Jongbloed AW, Bikker P, Thissen JT (2011) Dose-response relationship between dietary copper level and growth performance in piglets and growing -finishing pigs and effect 
of withdrawal of a high copper level on subsequent growth performance. Report 483, Wageningen UR Livestock Research. http://www.livestockresearch.wur.nl

Kim JC, Hansen CF, Pluske JR, Mullan BP (2010) Evaluating the replacement of zinc oxide with an encapsulated zinc oxide product as a means of controlling post-weaning diarrhea in piglets. Murdoch University, Project 2C-114. http://apri.com.au/2C-114_Final_report

Lampromsuk P, Bunchasak C, Kaewtapee C, Sawanon S, Poeikhampha $T$ (2012) Effect of supplementing acidifiers and organic zinc in diet on growth performances and gut conditions of pigs. J Appl Sci 12: 553-560.

Li J, Li DF, Xing JJ, Cheng ZB, Lai CH (2006) Effects of $\beta$-glucan extracted from Saccharomyces cerevisiae on growth performance, and immunological and somatotropic responses of pigs challenged with Escherichia coli lipopolysaccharide. J Anim Sci 84: 2374-2381.

Li X, Yin J, Li D, Chen X, Zang J, Zhou X (2006a) Dietary supplementation with zinc oxide increases Igf-I and Igf-I receptor gene expression in the small intestine of weanling piglets. J Nutr 136: 1786-1791.

Lipinski K, Mazur M, Antoszkiewicz Z, Makowski Z (2014) The effect of dietary supplementation with a herbal product, a bland of organic acids and zinc oxide on nutrient digestibility and growth performance in weaned piglets. Pol J Natur Sc 29: 119-127.

Liu P, Pieper R, Rieger J, Vahjen W, Davin R, Plendl J, Meyer W, Zentek J (2014) Effect of dietary zinc oxide on morphological characteristics, mucin composition and gene expression in the colon of weaned piglets. PloS one 9: e91091.

Malka E, Perelshtein I, Lipovsky Y, Shalom Y, Naparstek L, Perkas N, Patrick T, Lubart R, Nitzan Y, Banin E, Gedanken A (2013) Eradication of multi-drug resistant bacteria by a novel $\mathrm{Zn}$-doped $\mathrm{CuO}$ nanocomposite. Small 9: 4069-4076.

Mavromichalis I, Peter CM, Parr TM, Ganessunker D, Baker DH (2000) Growth-promoting efficacy in young pigs of two sources of zinc oxide having either a high or a low bioavailability of zinc. J Anim Sci 78: 2896-2902.

McAlpine P, O'Shea CJ, Varley PF, Flynn B, O'Doherty JV (2012) The effect of seaweed extract as an alternative to zinc oxide diets on growth performance, nutrient digestibility, and fecal score of weaned piglets. J Anim Sci 90: (Suppl 4): 224-226

Missotten JA, Goris J, Jakobsen M, Van Coillie E, Herman L, De Smet S, Dierick NA, Heyndrickx M (2009) Screening of isolated lactic acid bacteria as potential beneficial strains for fermented liquid pig feed production. Anim Feed Sci Technol 150: 122-138.

Morales J, Cordero G, Pineiro C, Durosoy S (2012) Zinc oxide at low supplementation level improves productive performance and health status of piglets. J Anim Sci 90: 436-438

Moreno MA (2014) Survey of quantitative antimicrobial consumption per production stage in farrow-to-finish pig farms in Spain. Vet Rec Open 1. e000002

Mullan BP, Wilson RH, Harris D, Allen JG, Naylor A (2007) Supplementation of weaning pig diets with zinc oxide or Bioplex TM Zinc. Pig Industry, 1288. en.engormix/pig/supplementation-weaner-pig/141-pO

NRC (National Research Council) (2005) Mineral tolerance of domestic animals. Second revised edition. The National Academies Press, Washington D.C. www.nap.edu.read/ 11309/chapter/1
Perez VG, Waguespack AM, Bidner TD, Southern LL, Fakler TM, Ward TL, Steidinger M, Pettigrew JE (2011) Additivity of effects from dietary copper and zinc on growth performance and fecal microbiota of pigs after weaning. J Anim Sci 89: 414-425.

Pieper R, Vahjen W, Neumann K, Van Kessel AG, Zentek $\mathrm{J}$ (2012) Dose-dependent effects of dietary zinc oxide on bacterial communities and metabolic profiles in the ileum of weaned pigs. J Anim Physiol Anim Nutr (Berl) 96: 825-833.

Regulation No 1831/2003, Regulation of the European Parliament and of the Council. Official Journal of European Union, 2003, L 268/29 eur-lex.europa.edu/legal-content/ $\mathrm{EN} / \mathrm{TXT} /$ ? uri

Roof MD, Mahan DC (1982) Effect of carbadox and various dietary copper levels for weanling swine. J Anim Sci 55: 1109-1117.

Sargeant HR, McDowall KJ, Miller HM, Shaw MA (2010) Dietary zinc oxide affects the expression of genes associated with inflammation: Transcriptome analysis in piglets challenged with ETEC K88. Vet Immunol Immunopathol 137: $120-129$.

Shelton NW, Tokach MD, Nelssen JL, Goodband RD, Dritz SS, DeRouchey JM, Hill GM (2011) Effects of copper sulfate, tri-basic copper chloride, and zinc oxide on weanling pig performance. J Anim Sci 89: 2440-2451.

Sirelkhatim A, Mahmud S, Seeni A, Kaus NH, Ann LC, Bakhori SK, Hasan H, Mohamad D (2015) Review on zinc oxide nanoparticles: antibacterial activity and toxicity mechanism. Nano-Micro Letters 7: 219-242.

Slifierz MJ, Friendship R, Weese JS (2014) Zinc Oxide therapy increases prevalence and persistence of methicillin-resistant Staphylococcus in pigs: a randomized controlled trial. Zoonoses Public Health 62: 301-308.

Tayel AA, El-Tras WF, Moussa S, El-Baz AF, Mahrous H, Salem MF, Brimer L (2011) Antibacterial action of zinc oxide nanoparticles against foodborne pathogens. J Food Safety 31: 211-218.

Thacker PA (2013) Alternatives to antibiotics as growth promoters for use in swine production: a review. J Anim Sci Biotechnol 4(35): 1-12.

Thati V, Roy AS, Prasad A, Shivannavar CT, Gaddad SM (2010) Nanostructured zinc oxide enhances the activity of antibiotics against Staphylococcus aureus. J Biosci Tech 1: 64-69.

Turner JL, Dritz SS, Minton JE (2001) Alternatives to conventional antimicrobials in swine diets. Prof Anim Sci 17: $217-226$.

Vondruskova H, Slamova R, Trckova M, Zraly, Pavlik I (2010) Alternatives to antibiotic growth promoters in prevention of diarrhoea in weaned piglets: a review. Vet Med 55: 199-224.

Wang Z, Burwinkel M, Chai W, Lange E, Blohm U, Breithaupt A, Hoffmann B, Twardziok S, Rieger J, Janczyk P, Pieper R, Osterrieder N (2014) Dietary Enterococcus faecium NCIMB 10415 and zinc oxide stimulate immune reactions to trivalent influenza vaccination in pigs but do not affect virological response upon challenge infection. Plos one 9: e87007.

Yin J, Li X, Li D, Yue T, Fang Q, Ni J, Zhou X, Wu G (2009) Dietary supplementation with zinc oxide stimulates ghrelin secretion from stomach of young pigs. J Nutr Biochem 20: 783-790. 
Zhang B, Guo Y (2009) Supplemental zinc reduced intestinal permeability by enhancing occluding and zonula occludens proteins 1 (ZO-1) expression in weaning piglets. Br J Nutr 102: 687-693.
Zhou W, Kornegay ET, Lindermann MD, Swinkels JW, Welten MK, Wong EA (2014) Stimulation of growth by intravenous injection of copper in weanling pigs. J Anim Sci 72: 2395-2403. 